\title{
sciendo
}

\section{WITH THE LITLE HELP FROM JANIS JOPLIN}

\author{
PETER MICHALOVIČ \\ Katedra estetiky, Filozofická fakulta Univerzity Komenského v Bratislave
}

\begin{abstract}
Abstrakt: Mad’arský spisovatel' a esejista Péter Esterházy (1950 - 2016) krátko pred smrtou napísal pre Slovenské národné divadlo dramatický text Mercedes Benz-Historická revue v dvoch častiach. Dotýka sa predovšetkým pôsobenia slávneho šlachtického rodu Esterházy na Slovensku, ku ktorému mal autor hry blízky vztah. Péter Esterházy vo svojom písaní využíva široké možnosti intertextuality: jeho literárne texty predstavujú tkanivo spradené z vláken autobiografie dejín vlastného rodu, d’alej z fragmentov uhorskej, neskôr mad’arskej a slovenskej histórie, legiend, povestí a nezriedka aj klebiet či fám. Interpretovaný dramatický text je pozoruhodný tým, že Esterházy popri intertextuálnom recyklovaní svojich textov exploatuje aj text mad’arského klasika Imre Madácha Tragédia človeka. Autor štúdie sa zameral na objasnenie funkcie, špecifík a efektov Esterházyho intertextuálneho písania.
\end{abstract}

Klúčové slová: intertextualita, mimézis sveta a mimézis textu, objektový jazyk a metajazyk

\section{Namiesto úvodu}

Dňa 7. 1. 2017 mala v Slovenskom národnom divadle premiéru divadelná hra Pétera Esterházyho Mercedes Benz - Historická revue v dvoch častiach. Nestáva sa často, že svetovo uznávaný spisovatel' napíše divadelnú hru pre Slovenské národné divadlo, ktoré sa vd’aka tomu môže chválit’ svetovou premiérou. Bez akýchkolvek pochybností teda išlo o mimoriadnu kultúrnu udalost’ roku 2017, významom presahujúcu hranice Slovenska. Zásluhy patria najmä trom l’ud’om: Esterházyho dlhoročnému blízkemu priatel'ovi a vydavatel'ovi slovenských prekladov jeho kníh Lászlóovi Szigetimu, dramaturgovi a prekladatelovi Petrovi Kováčovi a režisérovi Romanovi Polákovi.

Zaiste existovalo vel’a dôvodov k napísaniu tejto hry, jedným z nich bol nesporne vplyv rodu Esterházyovcov na dejiny Slovenska. Okrem toho, Péter Esterházy hlasno brojil proti nacionalizmu, pričom jeden zo spôsobov jeho eliminácie videl v literárnom spracovaní stôp, ktoré po sebe zanechali historické udalosti. Jeho ambíciou bolo vytvorit z týchto stôp literárne naratívy, ktoré by poskytovali tol'ko estetickej rozkoše, kol'ko hrdlo ráči.

Uvedenie hry v SND ma primälo k interpretácii dramatického textu, na základe ktorého sa realizovala divadelná performancia. Skutočnost', že sa zaoberám výlučne dramatickým textom, je limitovaná mojou vedeckou kompetenciou, hoci si uvedomujem, že samotná inscenácia si zasluhuje osobitnú interpretáciu. ${ }^{1}$

\footnotetext{
${ }^{1}$ Otvorene priznávam, že popri verejných a všeobecne známych skutočnostiach jestvuje aj jeden súkromný dôvod, prečo som sa rozhodol napísat tento text: s Péterom Esterházym ma spájalo vyše pätnástročné priatel'stvo. Ako jednému z mála l’udí zo Slovenska sa mi dostalo tej cti, že som mohol prispiet’ textom Chcete
} 


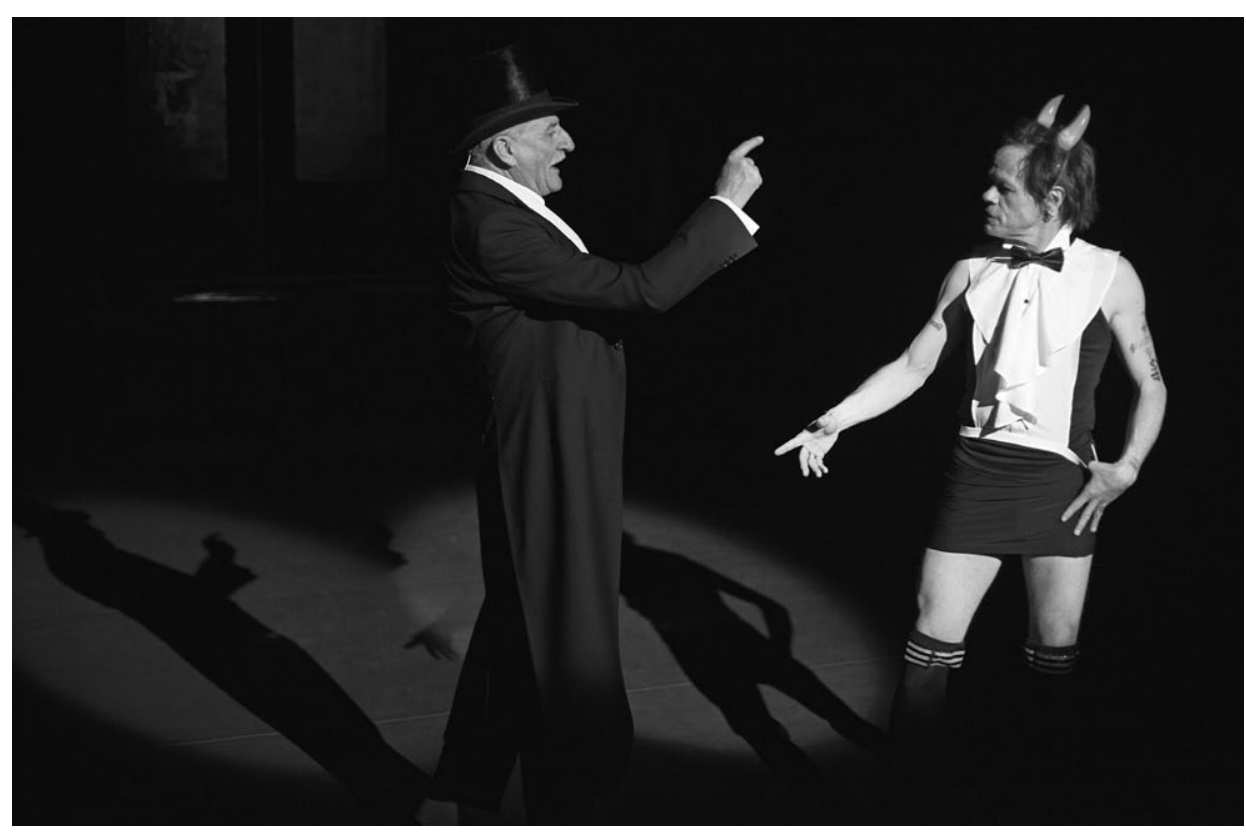

Péter Esterházy: Mercedes Benz - Historická revue v dvoch častiach. Slovenské národné divadlo, premiéra 7. 1. 2017. Réžia Roman Polák. Martin Huba (Pán), Robert Roth (Lucifer). Foto archív SND. Snímka Andrej Čanecký.

\section{Dve stratégie písania}

V roku 2006 vyšla v Českej republike kniha s názvom Príbeh. Pozostáva z dvoch samostatných textov. Autorom prvého je Imre Kertész a má názov Protokol, autorom druhého je Péter Esterházy a má názov Život a literatúra.

Kertész napísal svoju poviedku v roku 1991. Rozpráva v nej príbeh jednej nevydarenej cesty Imreho Kertésza - empirického a modelového autora v jednej osobe. Kertészovi udelil Antropologický ústav vo Viedni štipendium a jedného dňa sa rozhodne, že si ho vyzdvihne. Kúpi si spiatočný lístok, v Budapešti nasadne do

vidiet’ zlatú Budapešt'? do monotematického čísla časopisu Kalligram, ktoré redakcia pripravila k autorovým päṫesiatym narodeninám. Vd’aka príspevku som dostal pozvanie na majstrove oslavy narodenín. $\mathrm{Na}$ údiv mnohých mad’arských intelektuálov sa oslava konala v Slovenskom inštitúte v Budapešti. Na záver oficiálnej časti som sa dočkal vel'kého prekvapenia: mladí herci z Komárna zdramatizovali môj vskutku krátky divadelný kus. U zúčastnených vyvolal búrlivý smiech. Potešilo ma to, pretože som chcel dosiahnut’ presne tento pragmatický účinok. Nadránom, po neoficiálnej časti oslavy, sa jubilant s nami rozlúčil, ked’že za pár hodín odlietal do Tokia na autogramiádu japonského prekladu svojej knihy. Odvtedy som sa s Péterom sporadicky stretával. Vlastne sme viedli pätnást’ rokov trvajúci prerušovaný dialóg o funkcii literatúry, o dejinách, nacionalizme, o literárnom jazyku. Po čase sme sa opät mali stretnút na slávnostnom obede v Budapešti, ktorý podával vel’vyslanec Slovenskej republiky v Mad’arsku, J. E. Rastislav Káčer, na Vel’vyslanectve SR v Mad’arsku pri príležitosti Péterových šest’desiatych piatych narodenín. Žial', pre neodkladné pracovné povinnosti som milé pozvanie musel odmietnut a s Péterom som sa už nevidel. Zakrátko mu diagnostikovali zhubnú rakovinu pankreasu, na jej následky 14. júla 2016 zomrel. Pochovaný je v obci Ganna, kde sa nachádza kostol s rodinou hrobkou Esterházyovcov, ktorú rodine darovala Mária Terézia. 
vlaku, v kupé si otvorí denník Salvatora Dalího Diary of Genius a začne čítat. Za mestom Tatabánya však nastanú neočakávané komplikácie. Colník u neho nájde neprihlásených štyritisíc šilingov, čo je dôvodom ich zhabania a Kertészovho vysadenia z vlaku. Nasleduje ponižujúci výsluch, vyjednávanie s hraničiarmi a nakoniec zaplatenie pokuty. Po strastiplnej ceste sa ponížený a unavený Kertész vracia večer do Budapešti, odkial' ráno vyrazil do Viedne. ${ }^{2}$

Toto je zjednodušená fabula poviedky. Vieme, kde sa jej príbeh začína, zauzluje, kulminuje, vieme aj, kde končí. Od samotného príbehu treba odlíšit jeho zmysel, teda to, čo sa pisatel' a autor v jednej osobe pokúsil čitatel'om priblížit', a tým je najmä pocit poníženia. Kertész patrí medzi tých spisovatelov, ktorí od čitatelov chcú, aby jeho literárne texty považovali za skutočnost', aby ich chápali ako dôveryhodné svedectvá toho, čo sa mu v živote stalo, alebo sa stalo niekomu inému. Táto stratégia písania je typická pre všetky varianty realizmu. Pre Kertésza je literárny text prostriedkom komunikácie: má umožnit’ čitatel’ovi vžit’ sa do kože obete, do kože dourážaného a poníženého človeka, žijúceho, či skôr živoriaceho v konkrétnom svete. Kertész ako spisovatel' chce (a potvrdzujú to aj iné jeho diela, napr. Fiasko alebo Človek bez osudu), aby čitatel' metodicky nevenoval pozornost' vrstve výrazov, ale aby ich vnímal len ako transparentné nosiče významov, a aby sa spoločnými silami podiel’ali na konštitúcii finálneho zmyslu textu. K tejto stratégii písania nesporne prispela aj spisovatelova skúsenost' života v koncentračnom tábore, a následne skúsenosť života v totalitnom režime. V každom prípade sú jeho literárne texty všeobecne prijímané a vysoko hodnotené ako dôveryhodné a sugestívne literárne svedectvá.

Esterházy napísal svoj text o dva roky neskôr než Kertész a jeho témou je taktiež poníženie. Presnejšie povedané, Esterházy ponúkol čitatel’ovu svoju verziu „colníckej historky“. Lenže tá, na rozdiel od Kertészovej, nie je a ani nechce byt’ napodobnením života. Naopak, za jeho textom stojí celkom iná stratégia písania, čo dokazuje aj táto formulácia z textu: „Na rozdíl od obvyklého chápání stojí u mne skutečnost a věta v obráceném gardu, já poměřuji větu skutečností, jinak řečeno nesleduji, jestli věta dobře popisuje skutečnost, nýbrž existuje-li takový kus skutečnosti, jaký popisuje má věta, neboli zda je má věta skutečná. $Z$ toho plyne: není-li věta, není skutečnost, nebo alespoň nevím, co s ní. “3

Esterházy, či presnejšie, modelový autor Esterházy striktne oddelený od empirického autora s identickým menom, vytvára akýsi prepis Kertészovho textu. Od Kertésza si zámerne vypožičiava celé vety a robí z nich súčast’ vlastnej historky. Napriek tomu, že sa v oboch textoch vyskytujú identické vety, ich význam je vždy iný, pretože je modifikovaný iným ecovským ko-textom, teda inými okolitými vetami jedného alebo druhého textu. Prítomnost' viet z Kertészovho textu je v Esterházyho texte evidentná. Využívanie týchto viet v novom texte slúži tak na zviditel’nenie označujúcich výrazov, oslabenie referencie a posilnenie autoreferencie, ako aj na využitie nových registrov písania, predovšetkým ironického. V konečnom dôsledku to vedie k zásadnej zmene pragmatických účinkov textu.

${ }^{2}$ Bližšie o tejto knihe pozri MICHALOVIČ, Peter. Literatúra: analógie a diferencie. In RUSINOVÁ, Zora - KRALOVIČ, Ján (eds.) Serialita a repetícia. Bratislava : Vysoká škola výtvarných umení, 2017, s. 180 - 194. ISBN 978-80-8189-015-4.

${ }^{3}$ ESTERHÁZY, Péter. Život a literatura. Prel. Dana Gálová. In KERTÉSZ, Imre - ESTERHÁZY, Péter. Př́běh. Praha : Academia, 2002, s. 52 - 53. ISBN 80-200-1456-X. 
A ešte jedna odlišnost’ tu vystupuje do popredia natol'ko, že ju nemožno prehliadnut'. Obrazne povedané, Dalího denník pomáha Kertészovi vycítit zákerný colníkov tón. Modelovému Esterházymu pomáhajú písat text viacerí spisovatelia, popri spomenutom Kertészovi sú to Franz Kafka, barón Péter Apor, Géza Otlik a hlavne Bernard Malamud, ktorý zase pomáha modelovému Esterházymu pochopit’ zmysel colníkovej reči. Na základe toho možno konštatovat', že Esterházyho autorský idiolekt je výsostne postmoderný. Literárny publicista Lajos Jánossy v rozhovore so spisovatel’om a Esterházyho rovesníkom Péterom Nádasom ${ }^{4}$ pripomenul, že Esterházy sa ironicky vyjadril o svojom statuse postmoderného spisovatel'a v tom zmysle, že je postmoderný, pretože doba je postmoderná, z čoho vyplýva, že všetci, ktorí v tejto dobe píšu, sú zákonite postmoderní. Nádas sa proti tomuto tvrdeniu ohradil. Povedal, že doba je síce postmoderná, ale je obrovský rozdiel medzi tým, kto tvorí na základe vlastnej literárnej látky alebo inej novej látky, a tým, kto tvorí z prevzatej látky. Ten, kto tvorí z vlastnej látky, je moderný spisovatel', kým ten, kto tvorí z prevzatej látky, presnejšie ani netvorí, len ju pretvára, je postmoderný. A v tomto zmysle možno Esterházyho považovat’ za postmoderného spisovatel’a par excellance. Síce verí, že text napodobňuje, ale napodobňovanie rozhodne nechápe ako klasické aristotelovské mimézis sveta. Skôr mu je bližšie dekonštruktivistické chápanie Jacquesa Derridua, v intenciách ktorého (umelecký) text nenapodobňuje svet, ale napodobňuje iné texty, živí sa ich fragmentmi a skladá ich do nového celku. A je úplne l’ahostajné, či to (umelecký) text priznáva alebo nie. Túto premisu dokazujú názorným spôsobom všetky Esterházyho literárne texty, pre mňa osobne predovšetkým útla kniha Pomocné slovesá srdca. ${ }^{5}$ Autor sa v nej vyrovnáva so smrtou matky, pričom mu vel'ký smútok zo straty milovanej osoby pomáhajú artikulovat’ jeho oblúbení mad’arskí a zahraniční spisovatelia. Ústrednou témou poslednej knihy Pankreasník ${ }^{6}$ je Esterházyho rakovina pankreasu. Prítomnost' zhubnej choroby prinútila spisovatel'a zapochybovat' o svojej stratégii písania, čo dokazuje táto pasáž: „Text je text je text, darmo ide o tzv. osobnú výpoved', správu, jestvovat' jestvuje ako text, takto to treba brat', zauvažoval som: to nie je celkom pravda, lebo občas sa za a pod nešikovnou (amatérskou) alebo už nekontrolovanou (pre blízkost' smrti) formuláciou môžu nachádzat’ dôležité informácie o živote, životoch, o konečnosti a nekonečnosti. " 7 Táto pochybnost', aj realizmus ako taký sú však v d’alších častiach textu jednoznačne zavrhnuté a identita intertextuálneho spisovatela je nanovo potvrdená.

\section{Exegéza dvoch paratextov}

Najčastejším typom paratextov sú názvy. V prípade hry Mercedes Benz sa môže zdat', že prvá časť názvu je jasná a nevyžaduje si nijakú exegézu. Každý, dokonca aj ten, kto sa o literatúru a divadlo nezaujíma, vie, že ide o značku slávnych nemeckých automobilov. Áno, aj k spomínaným automobilom odkazuje táto čast’ paratextu,

${ }^{4}$ Bližšie pozri NÁDAS, Péter - JÁNOSSY, Lajos. Közösek a céduláink. Nádas Péter a Esterházyról. In Litera.hu [online]. Dostupné na http://www.litera.hu/hirek/kozosek-a-cedulaink [cit. 10. 1. 2018].

${ }^{5}$ ESTERHÁZY, Péter. Pomocné slovesá srdca. Bratislava : Kalligram 2009. ISBN 978-80-8101-202-0.

${ }^{6}$ ESTERHÁZY, Péter. Pankreasník. Z mad’arského originálu Hasnyálmirigynapló (2016) prel. Renáta Deáková. Bratislava : Kalligram 2018, s. 7. ISBN 978-80-89916-58-0.

7 Tamže, s. 7. 


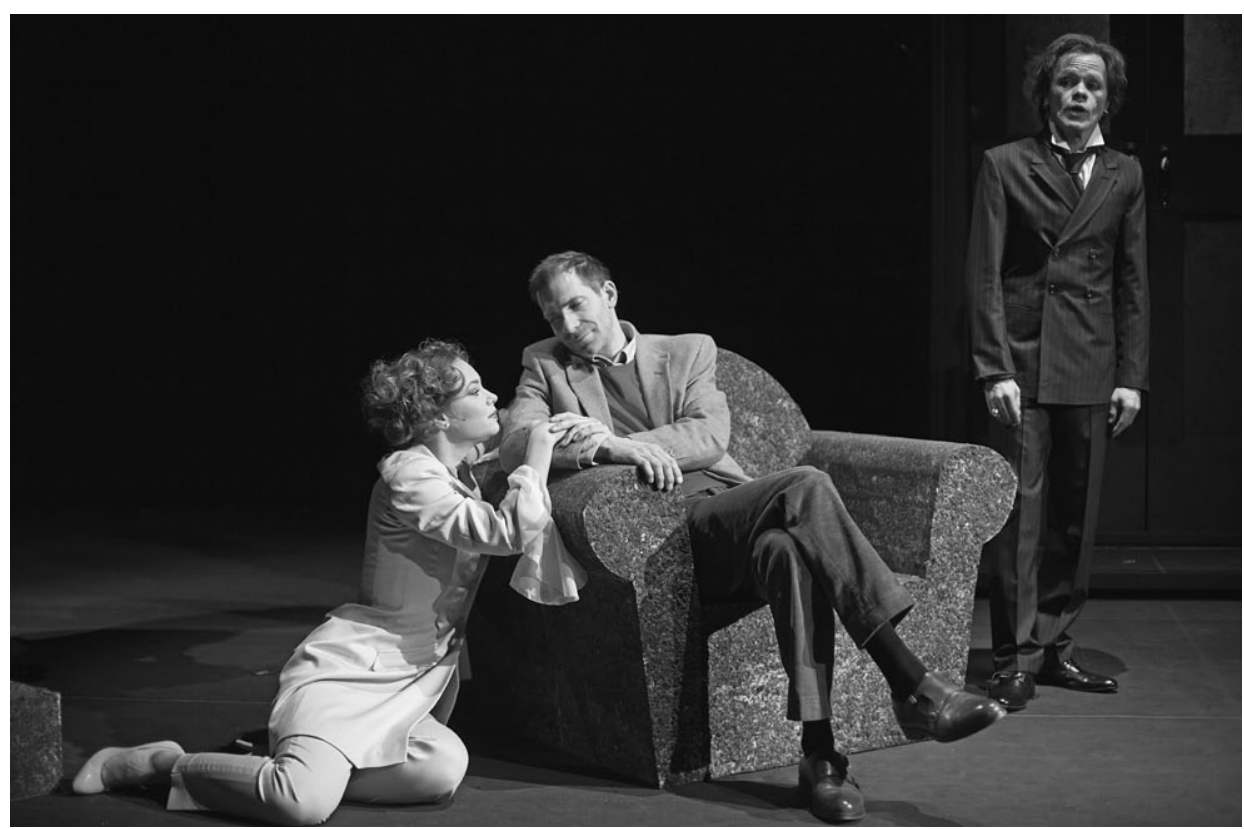

Péter Esterházy: Mercedes Benz - Historická revue v dvoch častiach. Slovenské národné divadlo, premiéra 7. 1. 2017. Réžia Roman Polák. Dominika Kavaschová (Prvá milenka), Ondrej Koval' (Gróf), Robert Roth (Lucifer). Foto archív SND. Snímka Andrej Čanecký.

lenže iba sprostredkovane. Primárne je pozornost’ sústredená na a capella song americkej speváčky Janis Joplin, ktorá predčasne zomrela vo veku 27 rokov. Táto vol'ba je ústami textového modelového grófa, čiže textového alter-ega empirického pisatel’a hry, zdôvodnená v dramatickom texte nasledovne: „Čo by sa stalo, ak by to bol Mercedes Benz od Janis Joplin? S tým neuveritel'ným smiechom na konci?... Boli by sme radi, keby inscenácia bola presne taká: strach, radost', nádej, bezvýchodiskovost'. Umývam si ruky, to je úloha režiséra, rezort pána Poláka... Ten smiech na konci... Silný, ale vydesený, a predsa veselý, drobný smiech. “8

Ten smiech Esterházyho jednoducho fascinoval, čo priznáva aj v Pankreasníku: „Povedal som im, aby si ešte dnes vypočuli Mercedes Benz a venovali zvláštnu pozornost' smiechu na konci. Mitics, najstaršia [spisovatel’ova dcéra - pozn. P. M.] sa najlepšie maskovala: máme ti to dat' zahrat' aj na pohrebe? No, ak by to šlo... Gitti [spisovatel’ova manželka - pozn. P. M.] krúti hlavou, nooo taaak..." ${ }^{\prime 9}$ Rodina splnila prianie umierajúceho spisovatela, song zaznel na poslednej rozlúčke v kostole a na pril'ahlom cintoríne v Ganne. Pripomeňme, že pieseň vyznieva ako zmes intímnej a zároveň verejnej spovede $\mathrm{k}$ Bohu, pričom táto paradoxná ambivalencia je principiálne nezrušitel’ná. Na jednej strane totiž speváčka prosí Boha, aby jej splnil niektoré želania, na druhej strane sa mu st’ažuje na svoj t’ažký život. Na konci zvláštnej piesňo-

\footnotetext{
${ }^{8}$ ESTERHÁZY, Péter. Mercedes Benz - Historická revue v dvoch častiach [programový bulletin]. Bratislava : Slovenské národné divadlo, 2017, s. 53 - 54.

${ }^{9}$ ESTERHÁZY, Péter. Pankreasník, s. 17.
} 
vej spovede zaznie spomínaný smiech, v ktorom sa podla Esterházyho ozývajú rôzne registre emócií. ${ }^{10}$ Všetci, ktorí sme sa rozlúčky s majstrom zúčastnili, sme vedeli, že pesnička mala pre neho vel'ký význam. Dodatočne to potvrdila aj vol'ba jej názvu za prvý paratext vlastného dramatického textu.

Aj Esterházyho dramatický text je akousi zvláštnou literárnou spoved’ou o tom, čo prežili jeho šl'achtickí predkovia. Spoved’ a osobná výpoved’ o tom, aké úspechy a príkoria priniesli rodu Esterházyovcov historické udalosti v Uhorsku a neskôr Mad’arsku, ako sa vel'ké dejiny krajiny a národa vždy prepletali s malými dejinami jeho rodiny, ako sa strach prelínal s radostou, nádej s bezvýchodiskovostou, smútok s bujarou zábavou. Referencia na históriu v jej rôznych modoch je explicitne obsiahnutá v prvej časti druhého paratextu "historická revue“. Popri adjektíve "historická" si zasluhuje pozornost' aj substantívum "revue“. Čo je vlastne revue? Z množstva významov je pre d’alší pohyb myslenia relevantný ten, ktorý vymedzuje revue ako žáner divadelnej zábavy. Ten pozostáva z relatívne samostatných výstupov, pričom každý výstup má špecifické afektívne kolorovanie. Práve táto rôznorodost' Mercedes Benz splña nároky revue, hoci aj historickej. Na druhej strane, menovaná heterogenita bráni estetickému zavŕšeniu dramatického textu: nedá sa určit', ktorý afekt by bolo možné považovat’ za dominantu a ktoré za subdominanty. Inak povedané, historická revue nie je ani tragédia či dráma, ani komédia, dokonca ani tragikomédia. Historická revue je jednoducho zmes alebo klaster. Teda niečo, čo sa nachádza na hranici divadelných žánrov, ale ani z jedného z etablovaných dramatických žánrov neobsahuje také množstvo príznakových ingrediencií, aby mohlo byt', hoci aj za cenu vel'kých ústupkov, považované za to alebo ono. Aby však bolo jasné, žánrovú nečistotu rozhodne nevnímam ako deficit. Práve naopak, je to prednost', pretože hre „à la revue“ umožňuje napíňat’ substantívum „historická“. Dejiny, nech by sme si to akokol'vek priali, nikdy nenapredujú lineárne od nižšieho k vyššiemu, od horšieho k lepšiemu, od nerozumného k rozumnému, od jednoduchého k zložitému. Napredujú od jednej udalosti k druhej, pričom jedna udalost’ poskytuje dôvod na radost',

\footnotetext{
${ }^{10}$ Text piesne Mercedes Benz (1970):

Oh Lord, won't you buy me a Mercedes Benz?

My friends all drive Porsches, I must make amends.

Worked hard all my lifetime, no help from my friends,

So Lord, won't you buy me a Mercedes Benz?
}

Oh Lord, won't you buy me a color TV ?

Dialing For Dollars is trying to find me.

I wait for delivery each day until three,

So oh Lord, won't you buy me a color TV?

Oh Lord, won't you buy me a night on the town ?

I'm counting on you, Lord, please don't let me down.

Prove that you love me and buy the next round,

Oh Lord, won't you buy me a night on the town?

\section{Everybody!}

Oh Lord, won't you buy me a Mercedes Benz?

My friends all drive Porsches, I must make amends,

Worked hard all my lifetime, no help from my friends,

So oh Lord, won't you buy me a Mercedes Benz ?

That's it! 


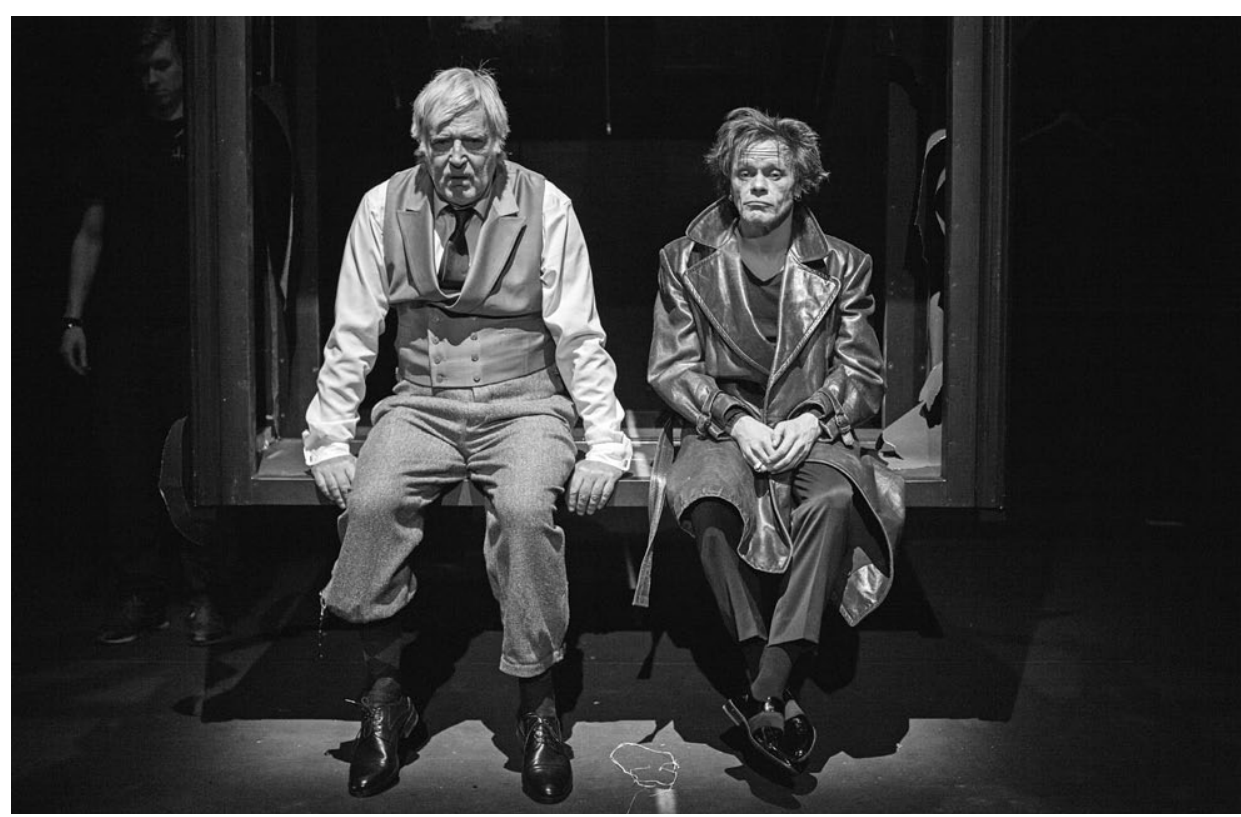

Péter Esterházy: Mercedes Benz-Historická revue v dvoch častiach. Slovenské národné divadlo, premiéra 7. 1. 2017. Réžia Roman Polák. Dušan Jamrich (Knieža), Robert Roth (Lucifer). Foto archív SND. Snímka Andrej Čanecký.

iná zase vyvoláva úzkost', strach či zdesenie. Malé dejiny rodu Esterházyovcov sú toho živým dôkazom.

\section{O dramatickom texte a jeho intertextuálnych vzt’ahoch s inými textami}

Po paratexte je treba sa venovat' samotnému dramatickému textu, lenže v tomto prípade je nemožné interpretovat’ text bez jeho vzt̉ahov s inými textami. Už po prvom čítaní je evidentné, že dramatický text predstavuje palimpsest, čo znamená, že pod povrchom čítaného textu presvitajú fragmenty iných textov. V nasledujúcej stati sa ich pokúsim priviest' na svetlo sveta a autorizovat'. Možno ich rozdelit do dvoch základných skupín. Do prvej skupiny patria texty, ktorých autorom nie je Esterházy, do druhej zase tie, ktorých autorom je.

Ak historickú revue aspoň niečo drží pohromade, hoci aj formálne, je to motív stávky Pána Boha s Luciferom. Tento motív nachádzame už v Svätom písme, konkrétne v Knihe Jób (1, 6 -12). Satan po prvý raz predstúpi pred Boha a Boh mu hovorí o dokonalom mužovi menom Jób. Je statočný, bojí sa Boha a chráni sa všetkého zlého. Satan tvrdí, že je to tak iba preto, lebo Boh urobil akoby ohradu okolo neho a jeho majetku. Ale akonáhle by na neho vztiahol svoju ruku, Jób by mu začal kliat do očí. Nato sa Boh rozhodne preverit’ Jóbovu vieru skúškami v podobe rôznych pohrôm či choroby. Ked' Jób odolá všetkým nástrahám, Boh ukončí túto stávku a Jóbovi ukáže svoju prozretel’nost', ktorá sa síce vymyká l’udskému chápaniu, ale v konečnom dôsledku je dobrá. Motív pokúšania nachádzame aj v iných literárnych textoch, stačí spomenút 
monumentálne dielo Johanna Wolfganga Goetheho Faust alebo vynikajúcu novelu Josepha Rotha Jób (1930).

V mad’arskej literatúre využil motív Jóbovej skúšky Imre Madách. V texte Tragédia človeka (1861) nahradil Jóba Adamom a v t’ažkostiach nechal preveritł jeho lojalitu voči Bohu i vieru v Božie dobro. Adamova cesta k Bohu je komplikovaná a strastiplná, nakoniec však triumfuje viera a pokora, vd’aka čomu sa Adamovi podarí zachránit’ nielen seba, ale celé l'udstvo. Tento motív využil aj Esterházy, teraz však na skúšanie pevnosti viery rodu Esterházyovcov. V jeho texte hovorí Pán o rodine: „Bývala aj tu v Bratislave, aj vo Viedni, sú to však Mad’ari... Slovom, mám rád túto rodinu už celé stáročia. Sú to dobrí l’udia.“ Na to replikuje Lucifer: „Dobrí l’udia neexistujú, iba takí, čo mali štastie.“ Pán však rodinu obhajuje: „Títo majú štastia dost', ved” ti hovorím, že ich mám rád. Tak im vezmi ich štastie a stavme sa, že ani potom sa neobrátia proti mne, ani v takom prípade nezradia dobro. ${ }^{\text {"11 }}$ Lucifer, posmelený slovami Pána, stávku prijíma a odoberie sa zobrat štastie tejto Pánom favorizovanej mad’arskej rodine v presvedčení, že stávku už vopred vyhral. Od tohto momentu až do konca hry Lucifer rodinu Esterházyovcov všemožne pokúša, škodí jej, ale tá napriek všetkým tažkým skúškam zostáva verná Bohu a dobru. Do textu sú priamo zakomponované (niekedy priznane, inokedy nie) citáty z Madáchovej Tragédie človeka, a tak sa stávajú súčastou kompozície nového textu.

Do druhej skupiny Esterházyho dramatických textov patria predovšetkým dva romány o otcovi: Harmonia cælestis (2005) ${ }^{12}$ a Opravené vydanie (2006) ${ }^{13}$. Prvý z nich rozpráva príbeh o otcovi, avšak nie o fyzickom, ani o symbolickom, či o vel'kom Otcovi vo freudistickom chápaní, ale o panotcovi, ktorý prežíva stáročia. Esterházy ozrejmuje: „Odborná literatúra rozlišuje dvadsat’dva rozličných druhov panotcov, z toho devätnást’ možno pokladat’ za dôležitých. " ${ }^{14}$ Panotec je v skutočnosti symbolický znak, či presnejšie, znak medzi inými znakmi semiotického univerza. Tento znak po stáročia intertextuálne blúdi z historky do historky, pričom historiek je obrovské množstvo. Sú to historky rozprávané prostredníctvom legiend a fám, ale aj historických naratívov. Ďalej sú to historky vyrozprávané šlachtou i pospolitým l’udom. Nezanedbatel’nou súčastou sú tiež historky vykonštruované oficiálnou komunistickou ideológiou. Tieto historky sú v románe Harmonia cælestis dopíňané historkami, ktoré majú konkrétneho autora - Pétera Esterházyho. Ten v texte vystupuje raz ako gróf-spisovatel', inokedy ako Péter Esterházy. Dvadsat’dva panotcov je tu zredukovaných na knieža a otca. Fiktívne historky sa miešajú s historkami z textov ideológov a historikov, s l’udovou slovesnostou, s historkami pochádzajúcimi od šl'achticov a šl’achtičných, cirkevných hodnostárov a vládcov monarchie, lokajov, kočišov, aj komunistických eštebákov. Ich prepojením vznikol text utkaný z rôznych vlákien, pričom táto heterogenita devalvuje faktické a valorizuje fiktívne. Čitatel', konfrontovaný s mohutným prúdom historiek, ktoré sa na neho valia ako obrovská lavína, sa nevie rozhodnút,' čo je pravda a čo klamstvo, čo je fakt a čo fik-

\footnotetext{
${ }^{11}$ ESTERHÁZY, Péter. Mercedes Benz - Historická revue v dvoch častiach [programový bulletin], s. 53.

${ }^{12}$ ESTERHÁZY, Péter. Harmonia cælestis. Bratislava : Kalligram, 2005. ISBN 80-7149-717-7. Názov románu je identický so zbierkou kantát, ktorú zložil gróf Pál Esterházy z Galanty, priamy predok spisovatel’a, ktorého oficiálny šlachtický titul je gróf Péter Esterházy z Galanty a Frakna.

${ }^{13}$ ESTERHÁZY, Péter. Opravené vydanie. Bratislava : Kalligram, 2006. ISBN 80-7149-895-5.

${ }^{14}$ ESTERHÁZY, Péter. Harmonia cælestis, s. 133.
} 


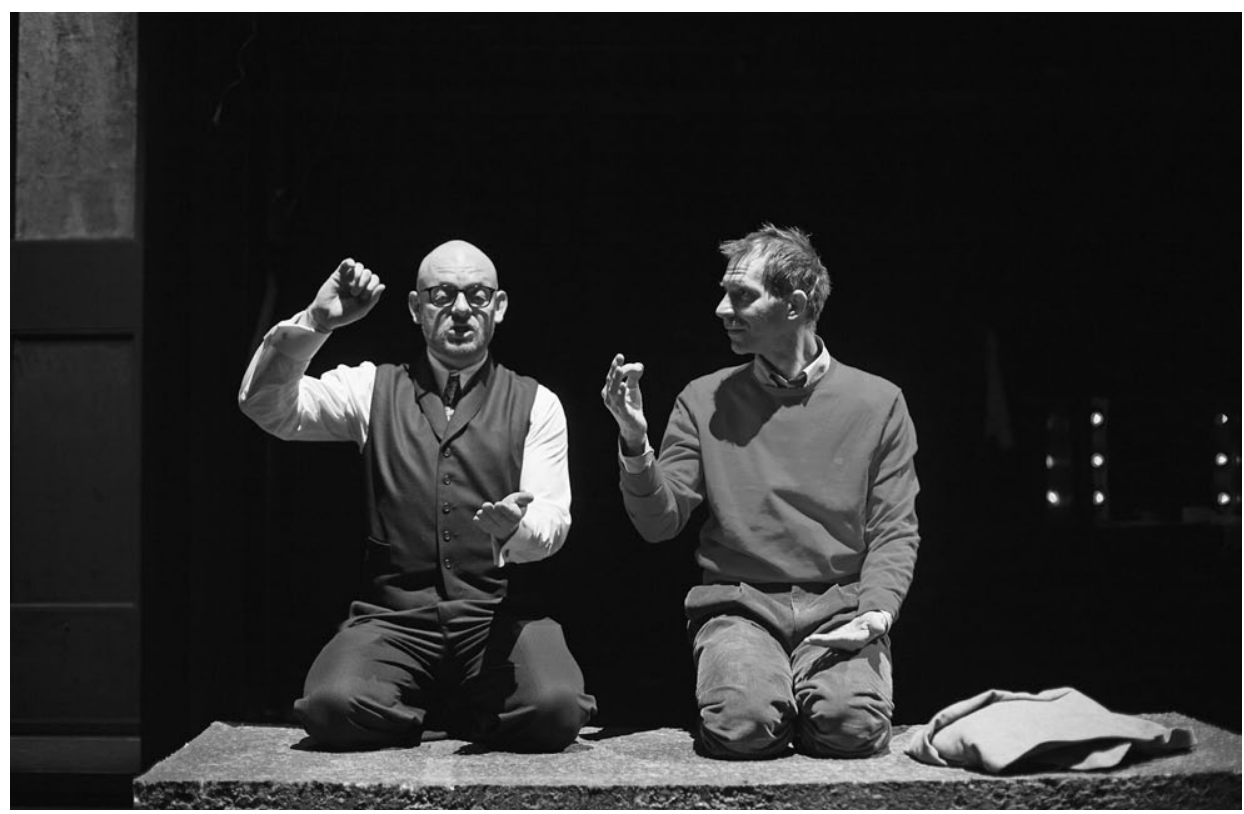

Péter Esterházy: Mercedes Benz-Historická revue v dvoch častiach. Slovenské národné divadlo, premiéra 7. 1. 2017. Réžia Roman Polák. Luboš Kostelný (Otec), Ondrej Koval' (Gróf). Foto archív SND. Snímka Andrej Čanecký.

cia. Vtedy si uvedomí, že protiklad pravdy a lži tu jednoducho nefunguje, a že ked' chce pochopit’, o čo vlastne ide, musí uverit’ prvej vete románu: „Potvorsky t’ažké je klamat', ked’ človek nepozná holú pravdu. “15

Ked’ bol Esterházy v tlačiarni, kde kontrolovali tlač knihy Harmonia cælestis, z telefonátu sa dozvedel, že jeho otec bol agentom ÁVO (Államvédelmi Osztály), čiže mad’arskej obdoby našej Šátnej bezpečnosti. Ako syn sa musel s týmto faktom vyrovnat'. A ako spisovatel' vedel, že sa s ním musí vyrovnat' výsostne literárnym spôsobom, preto napísal román Opravené vydanie. Je to trpký a smutný román. Jeho autor však dobre vie, že ak budeme poukazovat’ na udavačstvo iných a nezačneme sa s ním vyrovnávat' $\mathrm{v}$ okruhu najbližších, spoločnost’ sa neočistí od nánosov toxického bahna minulosti a nemôže zdravo napredovat. Formuluje to týmito slovami: „Prečo nevyrozprávajú cirkevní hodnostári svoj vlastný príbeh z kádárovského režimu? Sme svedkami toho, že spoločnost' ho nerozpráva, a cirkev ako taká (istá čast’ spoločnosti) tiež nie. Hovorí sa, že biskup často súhlasil so spoluprácou, aby tak uchránil seminaristov. Áno, aj to sa stávalo. A prečo by sa to teraz nemohlo odhalit? To, že k akým podlostiam podlá doba nútila. Stalo sa to, a toto som si myslel, a toto boli moje hl'adiská. Toto sú moje pravdy, a toto moje omyly. "16 Péter Esterházy aj v tomto románe

${ }^{15}$ Tamže, s. 11. Bližšie o tejto téme pozri MICHALOVIČ, Peter. Dve knihy o otcovi. In CHLEBOVÁ, Zuzana (ed.) Interpretácia textu v medziodborových súvislostiach. Bratislava : Univerzita Komenského v Bratislave, 2012, s. 46. ISBN 978-80-223-3147-0.

${ }^{16}$ ESTERHÁZY, Péter. Opravené vydanie, s. 229. 
využíva cudzie texty, používa predovšetkým citáty z otcovho spisu a zo záznamov agentov ÁVO. Vztahy medzi intertextuálnym exploatovaním nie sú v oboch románoch symetrické. Text Harmonia cælestis je recyklovaný v ovel'a väčšej miere než Opravené vydanie, zrejme aj preto, že Harmonia cælestis sa týka ovela dlhšieho historického obdobia.

\section{Krátka úvaha o poriadku a jeho rozvrátení}

Biblický príbeh o Jóbovi a dve knihy o otcovi tvoria základný materiál, z ktorého Esterházy vytvoril novú fabulu, teda súhrn lineárne a kauzálne zretazených udalostí. Biblický príbeh o Jóbovi slúži ako základný rámec dramatického textu, do neho sú dosadzované vybrané historky z dvoch kníh o otcovi. Hra je rámcovaná stávkou Pána a Lucifera, pričom Pán je vymedzený horizontálne vzt’ahom k Luciferovi a vertikálne vztahom k pozemskému svetu. V obidvoch prípadoch je Pán hierarchicky nadradený, hoci vo vzt’ahu k Luciferovi nie je táto hierarchia až taká viditel'ná ako vo vzt’ahu k pozemskému svetu. Pán vo vztłahu k pozemskému svetu nie je priamo zainteresovaný na dianí. Skôr naopak, voči tomu, čo sa deje v theatro mundi, zaujíma estetickú dištanciu. Avšak napriek tomu je prítomný a za všetkými udalostami treba vidiet’ aj Jeho.

Dialogickým partnerom Pána je Lucifer. Táto postava je značne komplikovaná, popri inom preto, že sa aktívne angažuje v záležitostiach pozemského sveta. Rád pokúša a navádza l’udí k páchaniu hriechov, čo je, koniec koncov, jeho pracovnou náplňou. Typickým povahovým znakom Lucifera je nepokoj, podnecovaný túžbou vyhrat’ nad Pánom a dokázat’ mu vierolomnost' l’udí, v tomto prípade zlyhanie Esterházyovcov. Pre svoje angažmány používa Lucifer rozličné masky, napr. masku advokáta, eštebáka či revolucionára. Popri tom využíva aj rôzne diskurzné žánre, predovšetkým biblický, právnicky a ideologický.

Dialógy Pána a Lucifera na seba nepútajú zbytočne vel’kú pozornost', slúžia skôr na prepojenie jednotlivých častí a výstupov. V nich sa čitatel' dozvie napríklad o osude jedného z otcov počas vojny medzi kurucmi a labancami, o účinkovaní Josepha Haydna na dvore Esterházyovcov v Eisenstadte a o jeho vztahu s Mikulášom Esterházym ${ }^{17}$, o vzt’ahoch mužských predkov s milenkami a slúžkami, o bitke pri Vozokanoch, v ktorej zahynuli hned’ štyria Esterházyovci, ale aj o prvom stretnutí kniežataa s komunistami či o brutálnom zasahovaní eštébákov do života Esterházyovcov: kniežat’a, otca a grófa-spisovatel’a.

Za vel'kými dejinami môžeme hl'adat' tak vôlu Pána, ako aj podvratnú činnost' Lucifera. Avšak reakcia na udalosti vel'kých dejín je v prvom rade závislá od vedomia a svedomia jednotlivca, od jeho rešpektovania alebo odmietania tradície či viery, od účelového oportunizmu atd'. Z tejto perspektívy predstavujú vel'ké dejiny vždy pokušenie vybrat’ si v danej situácii tú najl’ahšiu či najvýhodnejšiu cestu a prípadné osobné zlyhanie ospravedlnit floskulou: Taká bola doba, robil som len to, čo robili ostatní.

Príkladom odlišného chápania dejín, ktoré determinuje konanie, predstavujú výstupy revolucionára a kniežat’a. Každý z nich je vlastne hovorcom a zároveň posta-

\footnotetext{
${ }^{17}$ Knieža Mikuláš Esterházy bol vášnivým hráčom na barytón (nazývaný tiež viola da bardone, predchodca dnešného violončela). Joseph Haydn pre neho zložil 123 skladieb, ktoré je možné hrat’ aj na barytóne.
} 
vou jedného vel'kého príbehu. Na prvý pohl’ad sa môže zdat', že revolucionár vedie dialóg s kniežatom. Zdanie však klame, pretože v tomto prípade vedie nadosobná ideológia revolúcie dialóg s nadosobnou vierou a viac než tristopät’desiat rokov budovanou tradíciou. Je preto úplne jedno, kto momentálne hovorí v mene ideológie revolúcie a kto $\mathrm{v}$ mene viery, podstatný je dialóg, lebo ten $\mathrm{v}$ skutočnosti vedie oboch účastníkov. Revolucionár zvestuje kniežat’u, že už pätnást’ rokov je presvedčeným komunistom, na čo knieža ironicky odpovie, že už tristopätdesiat rokov je presvedčeným katolíkom. Koniec-koncov, v tom čase, ked’ revolucionár vstupoval do komunistickej strany a stal sa jej údajne presvedčeným členom, ani táto strana v Mad’arsku nemala ktoviekol'ko rokov. S určitou mierou vol'nosti ju možno považovał' za komplikované diet’a ešte komplikovanejších spoločensko-politických pohybov prvej tretiny 20. storočia. Tento historický hendikep si komunista dobre uvedomuje, a preto suverénne tvrdí kniežatu, že komunisti stvoria nový čas, nový letopočet, či dokonca novú novost'. Minulost' chápe len ako dlhú predohru k impozantnej hre prítomnosti, pričom ani netuší, že prítomnost' je od začiatku obetovaná utópii budúcnosti a táto utópia ich v konečnom dôsledku zabije. Výstižne to komentuje Pán, ktorý nepozná ani minulost', ani budúcnost', pretože je večnou prítomnostou: „Keby som chcel mat' aj budúcnost', prežral by som si ju dopredu a stal by sa zo mňa komunista. Komunisti už nie sú, nie je ani jeden. Nikde na svete. Zožrala ich vlastná moc. Sú len skorumpovaní ludia a šialenci, čo nazývajú komunistami seba samých. "18 Knieža je presvedčený o tom, že minulost’ je podmienkou prítomnosti, minulost’ de facto zakladá tradíciu a tradícia zase vytvára nás. Nie my myslíme tradíciu, ale tradícia myslí nás, je to akýsi duch, ktorý prechádza storočiami, preto je tradícia v tomto prípade stotožnená predovšetkým s vierou a Božím poriadkom. Ak bude tento poriadok rozvrátený v mene komunistovej či inej „,novej novosti“, svet môže očakávat’ katastrofu. Nie však definitívnu, pretože ten, kto vyhlási vojnu tradícii, vyhlási de facto vojnu viere, a kto vyhlási vojnu viere, vyhlási vojnu Najvyššiemu, a nad ním ešte nikto, nikdy a nikde nevyhral.

Rozvrátenie stáročia budovaného poriadku je obrazným spôsobom prirovnané ku kope obrazov, porcelánu a starožitných hodín. Každá z týchto vecí mala svoj význam a hodnotu, závislú od miesta vo svete kniežat’a, otca a grófa-spisovatela. Tento svet je svetom iba preto, lebo má svoj vlastný poriadok a v ňom každá vec zaujíma svoje konkrétne miesto v symbolickom priestore. Význam a hodnota vecí sú určené štruktúrou vztahov. Ak je táto štruktúra rozvrátená, usporiadaný celok sa zákonite zmení na niečo amorfné, čo rozpúšta všetky významotvorné a hodnototvorné diferencie. To je fakt, na ktorom nič nemení ani to, že aj komunisti neustále hovorili o celku. To isté, avšak ovel’a expresívnejšie tvrdí aj knieža pri pohl'ade na kopu: „Komunisti hovoria o celku a detaily rozkradnú. Pozrite sa, všetko, čím sa dá hýbat' - obrazy, zbierka porcelánu, starožitné hodiny - nahádzali na jednu kopu. Už to nie je obraz, ani porcelán, ani hodiny, už je to len kopa. Vidím to takto po prvý raz - a so všetkou istotou som $\mathrm{v}$ dlhej histórii našej rodiny prvý - a vidím, že ,vel'a' môže byt’ odporné. Po prvý raz vidím to ,vel'a' tak, že to nie je oslnivé bohatstvo, ani hojnost' stvorenia... ale kopa grcu uprostred môjho kaštiela, z ktorého sa človeku dvíha žalúdok. Títo červení to s vel'kou pravdepodobnostou zrejme vždy videli takto, ako neusporiadané

\footnotetext{
${ }^{18}$ ESTERHÁZY, Péter. Mercedes Benz - Historická revue v dvoch častiach [programový bulletin], s. 58.
} 
množstvo, nemohli poznat' históriu týchto vecí, vždy majú totiž do činenia iba s prítomnostou, nie s časom. Dokážu vidiet’ iba túto grcaninu, z ktorej sa dvíha žalúdok, množstvo, čo nahonobili títo grófski a kniežací hamstri... hamster... hamster, ako sa to povie po mad'arsky... presnejšie po slovensky?" ${ }^{\prime 19}$

V dramatickom texte vedie knieža dialóg aj s Herr Kappelmeisterom Haydnom, odhal'uje čitatelovi vzt’ah k slúžkam a milenkám, a najmä, vedie už spomínaný zvláštny rozhovor s revolucionárom. Vedie teda dialóg s l'ud'mi, ktorí žili v rôznych historických časoch a v nijakom prípade sa nemohli stretnút v jednom chronotope. Knieža spolu s otcom a grófom-spisovatel'om predstavujú kontinuitu minulosti s prítomnostou, ktorá predznamenáva budúcnost'. Samozrejme, tú reálnu, nie ideológmi velebenú utopickú budúcnost'.

\section{O objektovom jazyku a dvoch metajazykoch}

Dramatický text predstavuje priestor, v ktorom sa stretávajú, krížia, podporujú sa, ale si aj odporujú tri jazyky. Status prvého je najjednoduchší, pretože rozpráva o udalostiach, teda rozpráva historky a vyjadruje to, ako tieto udalosti prežívajú ich protagonisti. Týmto jazykom rozprávajú aj jednotlivé postavy. Ako taký sa v ničom podstatnom nelíši od iných jazykov väčšiny dramatických textov, a preto sa ním nebudem detailnejšie zaoberat. Pripomínam však, že objektový jazyk vytvára základné tkanivo textu, do ktorého sú votkávané vlákna pochádzajúce z d’alších dvoch metajazykov. ${ }^{20}$ Prvým z nich je jazyk, ktorým Pán a Lucifer komentujú dejové udalosti. Pán a Lucifer vždy vidia a vedia viac než jednotlivé postavy, a tak čitatel’ovi podávajú vysvetl'ujúce komentáre, ktoré umožnia lepšie pochopit’ motiváciu, úspechy, zlyhania, jednoducho zmysel konania postáv. Pán málokedy prehovára s postavami, zaujíma skôr estetickú dištanciu a udalosti vníma ako jednotlivé výstupy divadelnej hry. O tom, čo vidí, sa rozpráva s Luciferom a ponúka mu svoju interpretáciu udalostí. Naproti tomu, Lucifer síce diskutuje s Pánom, väčšinu času však trávi aktívnym zasahovaním do deja. Ako už bolo spomenuté, neustále pokúša a používa na to rôzne masky, často masku advokáta, ktorú možno chápat’ ako evidentnú alúziu na latinské advocatus diaboli. Lucifer nastavuje rafinované pasce, do ktorých majú padnút Esterházyovci. Jeho aktivita sleduje jediný ciel': zlomit ich vieru v Pána a dobro a dokázat’ Stvoritel’ovi, že každý sa dá zlomit', či už brutálnou silou alebo zvádzaním. Aby Lucifer mohol splnit’ svoj podlý ciel', musí komunikovat’ tak s Esterházyovcami, ako aj s l’ud’mi z ich okolia. V momente, ked’ sa stane súčastou deja, sa s postavami rozpráva výlučne objektovým jazykom. Ked' však komunikuje s Pánom, vystupuje z objektového jazyka a prechádza do zvláštneho metajazyka, takže je akousi temnou analógiou Herma, schopného nielen prekladat’ z jedného jazyka do druhého, ale tento preklad účelovo prispôsobovat' svojim podlým cielom. Diferencia medzi objektovým jazykom a metajazykom sprostredkovane zakladá aj diferenciu medzi pozemským a nadpozemským svetom, medzi akciou a estetickým

\footnotetext{
19 Tamže, s. 101.

${ }^{20}$ Teatrológovia, literárni vedci či jazykovedci môžu namietat', že by bolo vhodné zaoberat’ sa mnohými inými aspektmi objektového jazyka, napr. individuálnym štýlom, vztahom autorského idiolektu a postmoderného štýlu, vztłahom medzi doslovnostou a figuratívnostou, analýzou doslovného a figuratívneho, opisom ironického tónu atd'. Témou tohto textu sú však dva metajazyky a ich vztahy k objektovému jazyku.
} 


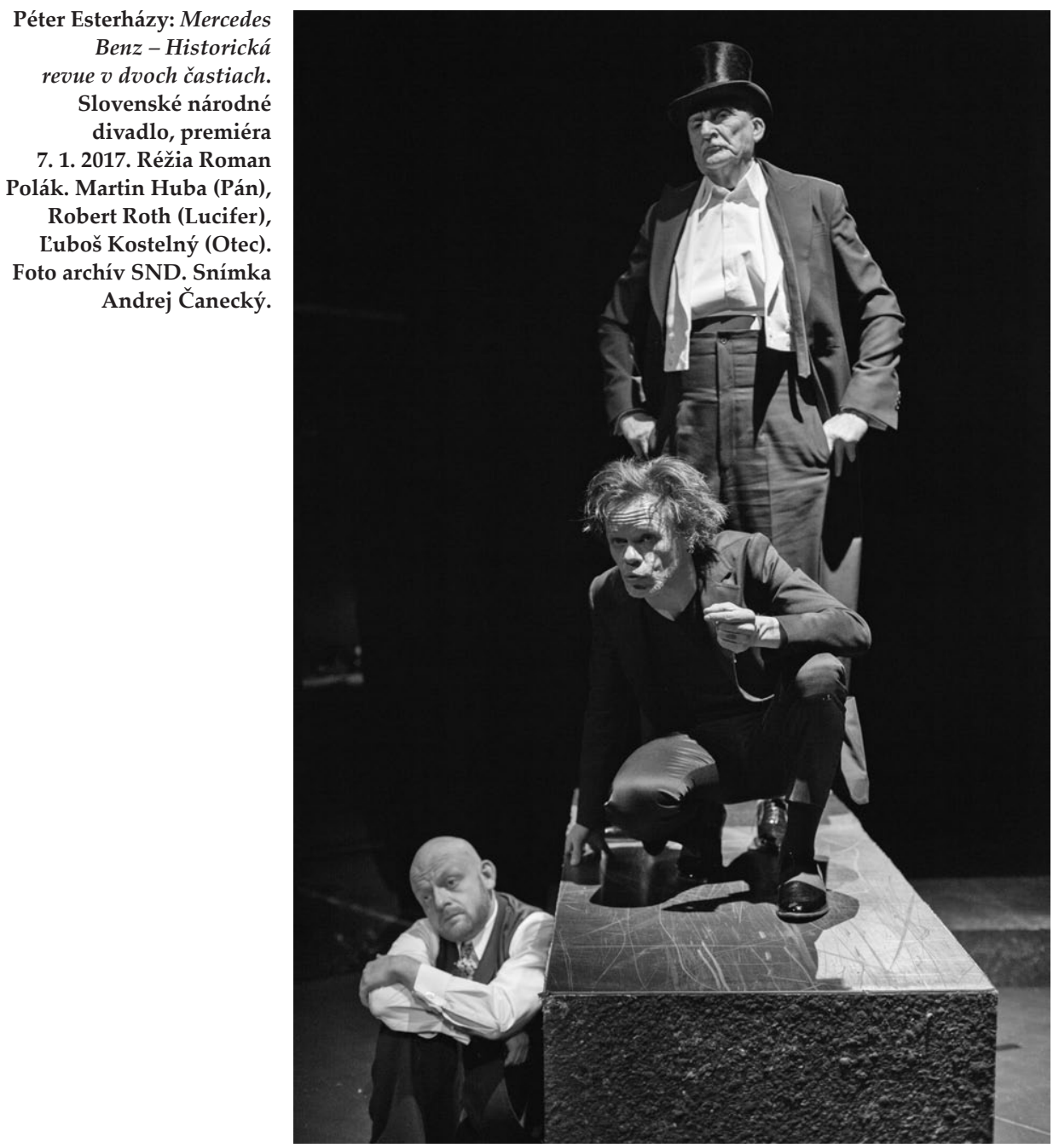

vnímaním akcie, medzi obmedzenými pohl’admi postáv a vševidiacimi pohl’admi Pána a Lucifera.

V hre sa objavuje ešte jeden metajazyk. Oproti prvým dvom jazykom sa dostáva k slovu len málokedy a prehovára ním výlučne autor. Aký autor? Rozhodne nie modelový autor, teda gróf-spisovatel', ktorý je súčastou textu a vypracováva jeho stratégiu, určenú svojmu partnerovi, ktorým je modelový čitatel'. Druhým metajazykom prehovára výlučne empirický autor s občianskym menom Péter Esterházy. Tento autor je pisatel'om hry, je majitel'om autorských práv, adresátom finančnej odmeny za napísanie hry a jej predvedenia, a zároveň ako právnická osoba zodpovedá za obsah hry. Na rozdiel od prvého metajazyka, ten druhý je prítomný zvláštnym spôsobom, prostredníctvom človeka, s ktorým sa o hre rozprávali režisér Roman Polák či prekladatel' a dramaturg Peter Kováč. Raz je prítomný aj v napísanom texte a takto sa 
prejavuje už v spomenutom citáte, v ktorom pisatel' oddel'uje svoju úlohu autora od úlohy režiséra Poláka. Od dramatického textu modelového autora je text empirického autora oddelený iným typom písma (kurzívou), takže sa dá l’ahko identifikovat.

Je všeobecne známe, že dramatický text predstavuje súbor nadindividuálnych inštrukcií, ktoré však poskytujú možnosti pre originálny interpretačný vklad režiséra. Esterházy si ako pisatel dobre uvedomuje, že jedna vec je jeho napísaná inštrukcia a druhá vec jej režisérska interpretácia. Možno to doložit niekolkými príkladmi: „(Aj toto je koniec d’alšej melódie. Alebo sú to krátke scénky, jasne od seba oddelené. Či sme to už azda spomínali?)“21 O niekol'ko strán sa k týmto vetám vráti: „(Slúžka sa vyval’uje vo foteli, listuje si v scenári. - Výstupy sú, na už spomínanej stene mojej fantázie, zretelne oddelené. Nechcem vnucovat' zlomkovitost', ale nechcime nikoho oklamat' falošným prísl'ubom kontinuálneho deja. “22 A d’alej čítame túto vetu: „(V rukách drží naklepaný papier, nie, je to skôr scenár hry, či radšej starý pergamen?, v takýchto situáciách sme radi, že nie sme Režisér.)“23 Mohli by sme pokračovat’ v enumerácii príkladov, predpokladám však, že tieto tri z nich dostatočne potvrdzujú status a povahu druhého metajazyka.

\section{Pokus o záver}

Najlepšie by bolo ukončił tento text tak, ako sa končí hra. Jednoducho pustit čitatel'ovi pieseň Janis Joplin Mercedes Benz a všetko nechat' na neho. Lenže v textovej podobe to nie je možné, takže povedzme aspoň to, že dramatický text Pétera Esterházyho je nesporne inšpirovaný postmoderným využívaním intertextuality v literatúre a že intertextualita je využitá na literárnu recykláciu toho, čo zanechali dejiny v podobe textuálnych stôp. Avšak v tomto prípade by sme popri všeobecne postulovanej intertextualite mohli brat' do úvahy aj inú intenciu, ktorou sú vzt’ahy malých dejín spisovatel'ovho rodu a vel'kých dejín strednej Európy. V tomto geografickom a politickom priestore sa príliš často menili režimy, prekresl’ovali sa hranice štátov, miešali sa jazyky, a zároveň sa jeden jazyk povyšoval nad iné. Skrátka, v každom momente dejín tohto regiónu sa do prítomnosti vrývala minulost’ a spôsobovala vel’a bolesti, smútku a strachu. Preto je načase zaobchádzat’ s minulostou esteticky, to znamená, brał' ju ako látku pre tvorbu príbehov, ktoré môžu zamedził’ d’alšej bolesti, smútku a strachu. Péter Esterházy sa o to pokúša, napríklad aj dramatickým textom, ktorý je predmetom tejto eseje. Jeho hra môže pomôct' Mad'arom aj Slovákom zbavovat’ sa nežiaducich predsudkov a začat’ sa voči dejinám správat tak, aby sa tí, čo prídu po nás, nemuseli hanbit’ za naše krutosti alebo sa vysmievat’ našim omylom a hlúpostiam. K Esterházyho textu sa treba opakovane vracat', pretože je v ňom viac, než si po prvom čítaní dokážeme uvedomit’.

\footnotetext{
${ }^{21}$ ESTERHÁZY, Péter. Mercedes Benz - Historická revue v dvoch častiach [programový bulletin], s. 69.

${ }^{22}$ Tamže, s. 73.

${ }^{23}$ Tamže.
} 


\section{WITH THE LITLE HELP FROM JANIS JOPLIN}

\section{Peter MICHALOVIČ}

Shortly before his death Hungarian writer and essayist Péter Esterházy (1950 - 2016) wrote the dramatic text of Mercedes Benz - Historical Revue in two parts for the Slovak National Theatre. In particular, it focuses on the famous noble family Esterházy's influence in Slovakia. The author of the play had a very strong association with this matter. In his writing Péter Esterházy used a wide range of intertextualities: his literary texts are like the fabric spun from fibres of the autobiography of his own family history, but also fragments of Hungarian and Slovak history, legends, tales, as well as hearsay and myths. The interpreted dramatic text is remarkable because Esterházy, in addition to intertextual recycling of his own texts, also exploits the texts of the Hungarian classic author Imre Madách The Tragedy of Man. The author of the study has focused on clarifying the function, specification and effects of Esterházy's intertextual writing.

Text vznikol v rámci grantového projektu VEGA 1/0446/17 - Filozofická, estetická a antropologická analýza úlohy médií a umenia v súčasných komunikačných procesoch.

Peter Michalovič

Katedra estetiky

Filozofická fakulta UK

Gondova 2

81499 Bratislava

e-mail: michalovic@fphil.uniba.sk 